\title{
CHANGES IN BLOOD DURING STORAGE FOR TRANSFUSION
}

KEY WORDS: Potassium, calcium, bicarbonate, blood transfusion

\section{Athanasios V. Bakaloudis \\ Marianna G. Andreadou \\ Irini M. Kalogiannidou}

Nazli O. Osman

Konstantinos $\mathbf{S}$. Mavromatidis*
General Practitioner, Consultant. Renal Department General Hospital of Komotini, Greece.

Microbiologist, Director.Blood Donation Department, General Hospital of Komotini, Greece.

Nephrologist, Consultant,Antoniou Dialysis Center "Dimokrition", Greece.

General Practitioner. Renal Department General Hospital of Komotini, Greece.

Nephrologist, Director, Antoniou Renal Department General Hospital of Komotini, Greece. *Corresponding Author

Introduction: Over the past 20 years, extensive research has been conducted on blood transfusion and the hazards arising from them, as well as on safest maximum storage duration for blood derivatives. Blood transfusion rates in patients with and-stage renal disease may have declined markedly after the discovery and use of erythropoietin in the mid-1980s, but is still remains a standard of care. Since several biochemical changes take place in stored blood, physicians should be alert when transfusing blood in end-stage renal disease patients, who are, theoretically at least, at higher risk of complications.

Methods and Results: This study were designed to investigate changes in storer blood over time (every 10 days from 0 to 40 days). Changes in sodium, potassium, chloride, total calcium, lactate, $\mathrm{pH}$, partial pressure of carbon dioxide, bicarbonate and hematocrit, as well as the degree of hemolysis, were recorded. The findings show a significant increase in potassium, lactate, partial pressure of carbon dioxide and hematocrit and a reduction in chloride, $\mathrm{pH}$ and bicarbonate. The serum levels of sodium initially increased (up to day 20 ) and then declined.

Conclusions: In conclusion, stored blood undergoes significant changes, which can be life-threatening, especially when the transfusions are massive or in patients with end-stage renal disease, who are more sensitive to significant $\mathrm{K}^{+}$or acid overload.

\section{INTRODUCTION}

The body's cells take their energy needs from the oxidative phosphorylation of glucose, but red blood cells, which do not have mitochondria, metabolize glucose anaerobically to create adenosine triphosphate (ATP), 2,3 diphosphoglyceric acid (2,3-DPG) and nicotinamide adenine dinucleotide (NADH), which are essential for their survival (1). The normal lifespan of red blood cells is 120 days; every second. $2,400,000$ new red blood cells are added to the circulation and the same amount of old red blood cells are removed (2).

Under blood storage conditions, the functioning of red blood cells is altered due to changes in their metabolism, increased oxidative stress and damage to their cell membranes (3). It has reported that oxidative stress is the predominant mechanism by which free hemoglobin $(\mathrm{Hb})$ is harmful for endothelial function and smooth muscle tone (4). According to the Food and Drug Administration, blood that is suitable for transfusion can be stored for the maximum of 42 days, although the average storage time for transfused blood in the US is 15 days (5). Or a little longer (6). In some European countries, the average storage period is 35 days (7). Recently, however, one study found that blood storage for more than 14 days contained few intact red blood cells (which are reported to survive for 32 days), while another has found that $23 \%$ of red blood cells were destroyed after 21 days of storage (2). Finally, others estimate that $30 \%$ of transfused red blood cells are removed from the circulation (destroyed) within 24 hours after the transfusion (8).

Some argue that transfusion complications are greater and more severe when blood is stored for a long time (9) and that the risk of such complications, which are often fatal, is higher in critically ill patients (such as patients with massive bleeding, renal failure and cardiovascular disorders) (10) and those who undergo open surgery because the extracorporeal circulation (9). Studies have linked transfusions with increased incidence of infection, multiple organ failure and increased morbidity and mortality (11). In this prospective study, wanted to identify the changes in stored blood over the time.

\section{MATERIAL AND METHODS \\ MATERIAL}

The blood donation department of our hospital collects about 4,000 bags of blood per year, of which about 30 are unsuitable for use due to their expiration date and about $20-30$ prove to be infectious after being checked and are, therefore, also considered inappropriate for use. In the present study, stored blood was examined to identify changes in levels of ions and molecules significant to the recipients. Blood from donors of group O, A and B (Rhesus +) was used for the study (i.e., the most common blood types were preferred). A total of 40 units of blood were taken from an equal number of blood donors. Plasma and the white layer (white blood cells) were removed by centrifugation (with cryocentrology) before storage. In the specific bags used for the protocol, the plasma remaining in each bag after centrifugation was estimated at $60-80 \mathrm{ml}$.

We used triple blood collection bags from Macopharma, which is appropriate for storage of red blood cells for 42 days. Each contains $63 \mathrm{ml}$ of anticoagulant solution (citratephosphate-dextrose, CPD) to receive $450 \pm 10 \mathrm{ml}$ of whole blood. After centrifugation of whole blood and removal of 15$180 \mathrm{ml}$ of plasma, $100 \mathrm{ml}$ of additive solution (saline-adenineglucose-mannitol, SAG-M) was added to the concentrated red blood cells.

The $\mathrm{pH}$, bicarbonate $\left(\mathrm{HCO}_{3}\right)$, partial pressure of carbon dioxide $\left(\mathrm{PvCO}_{2}\right)$, hematocrit $(\mathrm{Hct})$, sodium $\left(\mathrm{Na}^{+}\right)$, chloride $\left(\mathrm{CI}^{-}\right.$ 
), total calcium $\left(\mathrm{Ca}^{2+}\right)$ and lactate in each blood unit (bag) were determined, as well as the degree of hemolysis at the beginning (day of blood sampling) and every 10 days until the $40^{\text {th }}$ day storage.

\section{METHODS}

The blood units (concentrated red blood cells) were stored at $4{ }^{\circ} \mathrm{C}$ (the temperature was checked every 4 hours, and an alarm was installed that informed the staff of any changes in the storage temperature). No units were used after the end of the study.

Four samples for the study (every 10 days) were taken after good stirring (in a special stirrer) from the accompanying small bag of the package.

Levels of blood gases (and lactates) were determined on a Siemens RAPID 500 analyzer. Hct levels were tested on a Roche automatic hematology analyzer and levels of electrolytes $\left(\mathrm{K}^{+}, \mathrm{Na}^{+}, \mathrm{CI}, \mathrm{Ca}^{2+}\right)$ on an ion-selective analyzer, also from Roche. Mid hemolysis was considered when there was hemolysis in $<0.8 \%$ of red blood cells and moderate when it was in $<0.9 \%$.

\section{Statistical Analysis}

Analysis of variance (ANOVA), sequential analysis (post hoc) and t-tests were used for statistical analysis of the results. Differences with a significant level $<0.05$ were considered significant.

\section{RESULTS}

The ANOVA test showed a significant decrease in $\mathrm{pH}, \mathrm{HCO}_{3}$, $\mathrm{CI}$ and $\mathrm{Ca}^{2+}$ over time $(\mathrm{p}<0.0001$ in all cases). Sequential analysis (post hoc) showed that these changes were statistically significant after $10(p<0.0001), 20(p<0.0001), 30$ $(p<0.0001)$ and 40 days $(p<0.0001)$. While the $\mathrm{pH}$ decreased from $7.136 \pm 0.043$ after 10 days, it remained at a similar level for the rest of the test period (after 40 days, it was $6.5 \pm 0.0$ ). The $\mathrm{HCO}_{3}{ }^{-}$decreased from $24.33 \pm 1.78 \mathrm{mmol} / \mathrm{L}$ at the beginning of the study to $8.20 \pm 0.31$ on day 40 . The $\mathrm{CI}^{-}$was reduced from $97.4 \pm 1.7 \mathrm{mmol} / \mathrm{L}$ at the baseline to $89.3 \pm 2.7 \mathrm{mmol} / \mathrm{L}$ on day 40 , and the total $\mathrm{Ca}^{2+}$ decreased from $2.46 \pm 0.12 \mathrm{mmol} / \mathrm{L}$ at the beginning of the study to $0.99 \pm 0.19$ on day 40 . An examination of the changes in $\mathrm{pH}, \mathrm{HCO}_{3}^{-}, \mathrm{CI}$ and $\mathrm{Ca}^{2+}$ (comparisons between baseline and values after 10,20, 30 and 40 days) showed a statistically significant difference in all cases $(\mathrm{p}<0.001)$ (Table 1).

Table 1: Changes in pH, HCO3-, CI- and Ca2+ during the study (recordings took place during blood storage after sampling)

\begin{tabular}{|c|c|c|c|c|c|}
\hline & Beginning & $\begin{array}{c}\text { After 10 } \\
\text { days }\end{array}$ & $\begin{array}{c}\text { After 20 } \\
\text { days }\end{array}$ & $\begin{array}{c}\text { After 30 } \\
\text { days }\end{array}$ & $\begin{array}{c}\text { After 40 } \\
\text { days }\end{array}$ \\
\hline $\mathrm{pH}$ & $7.136 \pm$ & $6.714 \pm$ & $6.072 \pm$ & $6.550 \pm$ & $6.714 \pm$ \\
& 0.043 & 0.032 & 0.084 & 0.033 & 0.315 \\
\hline $\mathrm{HCO}_{3}^{-}$ & $24.33 \pm$ & $14.7 \pm$ & $13.5 \pm$ & $10.7 \pm$ & $8.20 \pm$ \\
$(\mathrm{mmol} / \mathrm{L})$ & 1.78 & 0.9 & 1.7 & 1.6 & 0.31 \\
\hline $\mathrm{CI}^{-}$ & $97.4 \pm 1.7$ & $93.9 \pm$ & $90.6 \pm$ & $88.8 \pm$ & $89.3 \pm$ \\
$(\mathrm{mmol} / \mathrm{L})$ & & 1.8 & 2.5 & 2.8 & 2.7 \\
\hline $\mathrm{Ca}^{2+}$ & $2.46 \pm 0.12$ & $1.85 \pm$ & $1.2 \pm$ & $1.05 \pm$ & $0.99 \pm$ \\
$(\mathrm{mmol} / \mathrm{L})$ & & 0.12 & 0.17 & 0.17 & 0.19 \\
\hline
\end{tabular}

The ANOVA test also showed a significant increased in $\mathrm{K}^{+}$, lactates, $\mathrm{PvCO} 2$ and Hct over time $(\mathrm{p}<0.001$ in all cases). Sequential analysis showed that the levels of these significantly increased after $10(p<0.0001), 20$ ( $p<0.0001), 30$ $(\mathrm{p}<0.0001)$ and 40 days $(\mathrm{p}<0.0001)$. More specifically, $\mathrm{K}^{+}$ increased from $4.4 \pm 0.1 \mathrm{mmom} / \mathrm{L}$ at baseline to $26.6 \pm 5.9$ $\mathrm{mmol} / \mathrm{L}$ on day 40 . The lactate levels increased from $3.0 \pm 0.2$ $\mathrm{mmol} / \mathrm{L}$ at the start of the study to $20.1 \pm 1.3 \mathrm{mmol} / \mathrm{L}$ on day 40 , and $\mathrm{PvCO}_{2}$ increased from $76 \pm 4.7 \mathrm{mmHg}$ at baseline to $114 \pm 13 \mathrm{mmHg}$ on day 40 . Finally, Hct levels increased from $42.1 \pm 2.1 \%$ at the start of the study to $52.4 \pm 4.3 \%$ on day 40 .
Comparisons between baseline and values after 10, 20, 30 and 40 days revealed a statistically significant difference in all cases $(\mathrm{p}<0.0001)$ (Table 2).

Table 2: Changes in $\mathrm{K}^{+}$, lactates, $\mathrm{PvCO}_{2}$, Hct and $\mathrm{Na}^{+}$ during the study (recordings took place during blood storage after sampling)

\begin{tabular}{|c|c|c|c|c|c|}
\hline & Beginning & $\begin{array}{c}\text { After 10 } \\
\text { days }\end{array}$ & $\begin{array}{c}\text { After 20 } \\
\text { days }\end{array}$ & $\begin{array}{c}\text { After 30 } \\
\text { days }\end{array}$ & $\begin{array}{c}\text { After 40 } \\
\text { days }\end{array}$ \\
\hline $\mathrm{K}^{+}$ & $4.4 \pm 0.1$ & $15.2 \pm 3.3$ & $20.4 \pm 4.6$ & $23.9 \pm 5.7$ & $26.6 \pm 6.0$ \\
\hline Lactates & $3.0 \pm 0.2$ & $11.1 \pm 0.7$ & $16.1 \pm 0.8$ & $17.8 \pm 0.8$ & $20.1 \pm 1.3$ \\
\hline PvCO $_{2}$ & $76.0 \pm 4.7$ & $118.0 \pm 12.6$ & $\begin{array}{c}129.3 \pm \\
24.2\end{array}$ & $\begin{array}{c}116.7 \pm \\
15.5\end{array}$ & $114 \pm 13$ \\
\hline $\mathrm{Hct}$ & $42.1 \pm 2.1$ & $55.4 \pm 5.2$ & $54.7 \pm 4.7$ & $52.4 \pm 4.4$ & $52.4 \pm 4.3$ \\
\hline $\mathrm{Na}^{+}$ & $141.3 \pm 1.2$ & $148.8 \pm 2.9$ & $145.0 \pm 4.4$ & $142.0 \pm$ & $140.1 \pm$ \\
& & & & 4.0 & 4.1 \\
\hline
\end{tabular}

Finally, the ANOVA test showed that $\mathrm{Na}^{+}$levels changes significantly initially $(p<0.0001)$ but not throughout the study. In particular, sequential analysis showed that $\mathrm{Na}^{+}$levels increased at a significant rate after $10(\mathrm{p}<0.0001)$ and 20 days $(p<0.0001)$ but not after $30(p<0.231)$ or 40 days $(p<0.427)$ (Table 2).

\section{DISCUSSION}

The modern material in which blood is stored are saline solutions containing citrate, glucose and mannitol (12).Whole blood is collected in triple bags. The first bag is empty for blood collection, and the second contains $63 \mathrm{ml}$ of CPD solution, consisting of sodium citrate (prevents blood clothing, binds calcium, citric acid (regulates $\mathrm{pH}$, achieving high concentration of hydrogen ions), sodium chloride and sodium bicarbonate (which provide isotonicity and ensure suitable osmolality). The third bag contains $100 \mathrm{ml}$ SAG-M solution, which contains mannitol (increase the osmolality of the extracellular space, protects against hemolysis and supports the integrity of the red blood cell membrane) (13), adenine (contributes to the survival of red blood cells by activating ATP production), dextrose (an energy source for red blood cells) and sodium monophosphate (supports ATP production and enhances glycolysis) (14).

A blood bag is suitable for transfusion in the US (when is stored for a maximum of 42 days at $4{ }^{\circ} \mathrm{C}$ ), if the $75 \%$ of its red blood cells are survive in the recipient's circulation for 24 hours after transfusion, and the existing hemolysis in the bag is less than $1 \%$ (0.8\% in Europe) (15-17). Hemolysis can occur during collection of the sample or during transport, but it may also occur due to irreversible changes in the erythrocyte membrane during storage (18).

Hemolysis was not detected in any bag until the $30^{\text {th }}$ day of blood storage. However, on the $40^{\text {th }}$ day of blood storage, $37 / 40$ bags were found to have $<1 \%$ hemolysis and were deemed suitable for transfusion.

In stored blood, leakage causes the redistribution of monovalent cations, as well as a higher intracellular concentration of bases (and therefore water), which leads to cellular oedema (19). Thus, the changes in the concentration of ions in the stored blood in SAG-M solution has an increasing effect on their volume. This difference is partly due to the absence of $\mathrm{Ca}^{2+}$.

Finally, during blood storage, a gradual increase in Hct was observed form day 0 to day 40. This is due to the fact that automated haematological analyzers do not determine Hct directly but do so indirectly by estimating the mean volume of red blood cells (MCVs), changes in which affect the Hct, which is also affected by the number of red blood cells (20), as observed in the present study.

The $\mathrm{Na}^{+}$in the blood bags decreased according to some researchers, when the storage time is longer (21). In fact, 
Ratcliffe et al. found a decrease in $\mathrm{Na}^{+}$from $170 \mathrm{mmol} / \mathrm{L}$ to 156 $\mathrm{mmol} / \mathrm{L}(13)$ after 35 days of blood storage. The reduction is due to the low storage temperature, which inhibits $\mathrm{Na}^{+}-\mathrm{K}^{+}-$ ATPase $(22,23)$, thereby increasing the concentration of $\mathrm{Na}^{+}$ intracellularly. Normally, this pump extract $3 \mathrm{Na}^{+}$from intracellular space and injects $2 \mathrm{~K}^{+}$outside (24) ions. However, in their study, Opoku-Okrah et al. found that the $\mathrm{K}^{+}$in stored blood increased by $0.5 \mathrm{mmol} / \mathrm{L}$ per day and that $\mathrm{Na}^{+}$ decreased by $0.59 \mathrm{mmol} / \mathrm{L}$ per day (25), meaning there was an equal change in the levels of these ions in the blood. These results were not found in the present study (Table 3); rather, an increase in $\mathrm{Na}^{+}$was noted after 10 and 20 days, following by a decrease.

Table 3: Changes of $\mathrm{K}^{+}$and $\mathrm{Na}+$ after 10, 20, 30 and 40 days

\begin{tabular}{|l|c|c|c|c|c|}
\hline Day & Beginning & $\begin{array}{c}\text { After 10 } \\
\text { days }\end{array}$ & $\begin{array}{c}\text { After 20 } \\
\text { days }\end{array}$ & $\begin{array}{c}\text { After 30 } \\
\text { days }\end{array}$ & $\begin{array}{c}\text { After 40 } \\
\text { days }\end{array}$ \\
\hline $\mathrm{K}^{+}$ & 4.4 & 15.2 & 20.4 & 24 & 26.6 \\
\hline $\mathrm{Na}^{+}$ & 141 & 148 & 145 & 142 & 141 \\
\hline $\begin{array}{l}\text { Change of } \\
\left(\mathrm{K}^{+}-\mathrm{Na}^{+}\right)\end{array}$ & & $\begin{array}{c}10.8 \\
\text { against 7 }\end{array}$ & $\begin{array}{c}16 \\
\text { against 4 }\end{array}$ & $\begin{array}{c}19.6 \\
\text { against l }\end{array}$ & $\begin{array}{c}22.2 \\
\text { against 0 }\end{array}$ \\
\hline
\end{tabular}

Potassium plays an important role in cellular metabolism, especially in the synthesis of albumin and glycogen and in the enzymatic process necessary for cellular energy production. It also helps to maintain the electrical neutrality and osmolality of cells. Other functions of $\mathrm{K}^{+}$include the regulation of acid-base balance, the stimulation of nerves and maintenance of a normal heart rhythm. It also contributes to the contraction of smooth and striated muscles. Moreover, a constant $\mathrm{K}^{+}$ concentration is important for cell division and growth.

Hyperkalemia after blood transfusions has been reported in the literature. While it is considered transient and "clinically non-significant" (26), deaths in newborns and young children from arrhythmias or cardiac arrest have been reported (27). Washing the red blood cells and removing the supernatant from the blood bags (leukapheresis) reduces this toxicity in high-risk recipients (28). Other studies were conducted on patients with trauma (without crush syndrome) to examine the effect of transfusion with blood that had been stored for 30-34 days on serum $\mathrm{K}^{+}$(two groups were compared: those transfused with more than 7 blood bags and those transfused with less). They found that those with more than 5 times more likely to have hyperkalemia. Other researches (29-31) have found that mass transfusion is associated with an increased incidence of hyperkalemia, which is not so much related to the amount of blood donated as to the rate of blood transfusion (30) and the number of days for which the units were stored, as well as to the presence or absence of hypovolemia.

Up to $60 \mathrm{mmol} \mathrm{K}^{+}$(32) has been recorded in the supernatant in blood bags. Opoku-Okran et al. (25) studying $\mathrm{K}^{+}$levels in 28 samples of stored blood and found an average increase from day 0 to day 20.These findings are supported by other studies of human subjects $(21,33,34)$ and experimental animals $(35)$. Ratcliffe et al. studied 115 blood samples and found a particularly significant increase in $\mathrm{K}^{+}$on day 38 (from 7 $\mathrm{mmol} / \mathrm{L}$ to $25 \mathrm{mmol} / \mathrm{L}$ (13), which corresponds to our findings (from $4.4 \pm 0.1 \mathrm{mmol} / \mathrm{L}$ at baseline to $26.6 \pm 5.9 \mathrm{mmol} / \mathrm{L}$ on day 40 ).

Of course, in patients with severe renal failure, even a small increase in serum $\mathrm{K}^{+}$can be dangerous, so the blood that they are given should be stored for less than 5 days (9).

Hyperkalemia has been reported in intensive care unit (ICU) patients who have received stored blood for less than 12 days. In fact, one of those who had a $\mathrm{K}^{+}$level of $9 \mathrm{mmol} / \mathrm{L}$ after receiving a transfusion of 7 units presented with heart failure and died. This was first study to reveal the factors responsible for hyperkalemia in severely ill ICU patients by determining $\mathrm{K}^{+}$levels immediately after administration of washed red cells (36). Heart attack has been reported in adults due to massive blood transfusions $(21,37,38)$.
Washing red blood cells reduces the $\mathrm{K}^{+}$load, but in emergencies (severely injured patients), there is no time for such preparation, so there is a risk of hyperkalemia (39). In fact, it seems that transfusion large amounts of stored blood at a rapid increase the risk of hyperkalemia in a small percentage of patients (36).

It is known that the distribution of $\mathrm{K}^{+}$in the body and its storage in the intracellular space is regulated by particularly important hormones (insulin, thyroxine, catecholamines) $(40,41)$. Its uptake by all cells is achieved by the action of $\mathrm{Na}^{+}-$ $\mathrm{K}^{+}$-ATPase. This makes the cell membranes particular permeable to $\mathrm{K}^{+}$, which enters in the intracellular space through its channels (24), while $\mathrm{K}^{+}$extracted from the cells through the $\mathrm{K}^{+}-\mathrm{H}^{+}$-antiporter and the $\mathrm{K}^{+}-\mathrm{CI}^{-}$-cotransporter.

During blood storage, there is a slow but steady movement of $\mathrm{K}^{+}$from the intracellular space to the plasma (based on the concentration gradient present). This is attributed to the inability of the $\mathrm{Na}^{+}-\mathrm{K}^{+}$-ATPase to act due to hypothermia during blood storage $(9,21,42)$ and not to a reduction in intracellular ATP levels (21). It has even been found that $\mathrm{K}^{+}$in blood increased by $0.5-1 \mathrm{mmol} / \mathrm{L}$ for each day of storage (43), which is in accordance with our findings in the present study. Thus, in blood storage for 21 or 35 days, the increase in plasma $\mathrm{K}^{+}$was 21.4 and $60.7 \%$, respectively $(9,13,44)$. In our samples, we observed a progressive increase in $\mathrm{K}^{+}$, which reaches an average of $26.6 \pm 5.9 \mathrm{mmol} / \mathrm{L}$ on day 40 , which was 6 times the level of potassium at the beginning of the study.

Investigators consider among other factors the change of $\mathrm{K}^{+}$to the secondary, caused by metabolic activities of cells (15). In particular, $\mathrm{K}^{+}$excretion from cells increases when extracellular osmolality increases (as in diabetes mellitus hyperglycaemia) due the mannitol and glucose in the perspective solution, as well as metabolic acidosis $\left(\mathrm{H}^{+}\right.$of extracellular space exchanged with $\mathrm{K}^{+}$of intracellular) (45). For each 0.1 unit decrease in $\mathrm{pH}$, the $\mathrm{K}^{+}$plasma increase by 0.4 $\mathrm{mmol} / \mathrm{L}$ (in the present study, this effect was small, since the $\mathrm{pH}$ increased from 7.136 to 6.650 , a change that justifies a $<3$ $\mathrm{mmol} / \mathrm{L}$ increase in $\mathrm{K}^{+}$). However, blood stored in CPDA-1 (citrate-phosphate-dextrose with adenine) has been to have 10 times more plasma $\mathrm{K}^{+}$on the $42^{\text {nd }}$ day of storage compared to the $1^{\text {st }}$ day due to increased fragility and deformability and reduced viability and survival of red blood cells $(46,47)$. Finally, large amounts of $\mathrm{K}^{+}$are released in the event of cell death.

Chloride levels increased during blood storage for the first 7 days and then decrease significantly (22). We found a gradual decrease in chloride levels from the day of blood sampling until day 40 . This is probably due to the entry of $\mathrm{K}^{+}$ intracellularly during blood storage.

Total calcium is reduced in stored blood (22), which is explained by the presence of citrates in the CPDA-1 solution $(43,44)$. This is supported by our findings that $\mathrm{Ca}^{2+}$ levels were found three times lower between the first day of blood storage and the $40^{\text {th }}$ day.

As mentioned, red blood cells do not have mitochondria and, therefore, derive their energy from anaerobic metabolism of glucose (thus producing metabolites such as ATP [the source of red blood cell energy], 2,3-DPG and NADH, which are necessary for their survival). The 2,3-DPG disappears from red blood cells after 2 weeks of blood storage (48). This deficiency increases the affinity of $\mathrm{HB}_{\text {for }} \mathrm{O}_{2}$, but 24 hours after transfusion, its levels return to the normal. Nicotinamide adenine dinucleotide is considered an important factor that contributes to the conversion of oxyhaemoglobin to methaemoglobin (the last contains $\mathrm{Fe}^{3+}$, and is not bound to $\mathrm{O}_{2}$ ) (50). At blood storage temperatures, cellular metabolism is maintained at baseline levels, reaching 10 times lower than normal. 
Glycolysis leads to an increase in lactate levels, which is mainly responsible for lowering $\mathrm{pH}(22)$. Lactate in stored blood has been reported to reach $8 \mathrm{mmol} / \mathrm{L}(13), 20 \mathrm{mmol} / \mathrm{L}$ (34), (which is supported by our finding) and even $25 \mathrm{mmol} / \mathrm{L}$ after 35 days of storage (13). In our case, the increase in $\mathrm{PvCO}_{2}$ was likely responsible for the decrease in $\mathrm{pH}$.

The hyperlactemia that we and others observed leads to a gradual decrease in ATP, 2,3-DPG and NADH. As a result, in $3^{\text {rd }}$ to $6^{\text {th }}$ week of storage, the blood's pH can reach 6.5 , as we noted on day $40^{\text {th }}$ of the present study $(2,15)$. Thus, the $\mathrm{pH}$ is maintained at relatively normal levels during blood storage, although it shows a tendency to decrease $(15,34,51)$. In fact, the literature shows a tendency of $\mathrm{pH}$ levels to reduce when metabolism is maintained without respiratory gas exchange (acidosis) (51).

Bicarbonates are significantly reduced in stored blood due to their consumption during the neutralization of lactates, which are produced during anaerobic glycolysis. This is despite the fact that in acidification, the $\mathrm{CI}^{-}-\mathrm{HCO}_{3}{ }^{-}$pump moves the extracellular $\mathrm{HCO}_{3}^{-}$to neutralize the $\mathrm{H}^{+}$(22). In our material, the $\mathrm{HCO}_{3}^{-}$levels sub-tripled from an average $24.33 \pm 1.78$ $\mathrm{mmol} / \mathrm{L}$ at the beginning of the study to $8.20 \pm 0.31 \mathrm{mmol} / \mathrm{L}$ on the day $40^{\text {th }}$ (from $3.04 \mathrm{mmol} / \mathrm{L}$ to $29.3 \mathrm{mmol} / \mathrm{L}$ ).

Preserved blood $\mathrm{PvCO}_{2}$ was significantly affected. Various studies $(13,34,51)$ have noted an increase similar to that observed in our study, which was from $76 \pm 4.7 \mathrm{mmHg}$ at the beginning to $114 \pm 13 \mathrm{mmHg}$ on day 40 . This change is attributed to the release of $\mathrm{CO}_{2}$ which comes from red blood cell metabolism (35).

The present study indicates that changes occurred in stored blood, some of which are life-threatening (especially hyperkalemia) and others not. Given these results, red blood cell bags for transfusions in patients with end-stage renal disease should be used in some days after donation (maybe less than five).

\section{REFERENCES}

1. Blasi B, D'Alessandro A, Ramundo N, Zolla L. Red blood cell storage and cell morphology.Transfus Med 2012;22(2):90-6.

2. Tuo WW, Wang D, Liang WJ, Huang YX. How cell number and cellular properties of blood-banked red blood cells of different cell ages decline during storage.PLoSONE. 2014;9:e105692.https://doi.org/10.1371/journal. pone.0105692

3. Orlov D, Karkouti K. The pathophysiology and consequences of red blood cell storage. Anaesthesia 2015;70 Suppl 1:29-37.

4. Boretti FS, Buehler PW, D'Agnillo F, et al. Sequestration of extracellular hemoglobin within a haptoglobin complex decreases its hypertensive and oxidative effects in dogs and guinea pigs.J Clin Invest 2009;1 19(8):2271-80.

5. World Health Organization. Dept. of Blood Safety and Clinical Technology, Safe blood and blood product. Manual on the management, maintenance and use of blood cold chain equipment. Geneva: World Health Organization 2005;92.

6. Sapiano MRP, Savinkina AA, Ellingson $\mathrm{KD}$, et al. Supplemental findings from the National Blood Collection and Utilization Surveys, 2013 and 2015. Transfusion 2017;57 Suppl 2: 1599-624.

7. Vermeulen Windsant IC, de Wit NC, Sertorio JT, et al. Blood transfusions increase circulating plasma free hemoglobin levels and plasma nitric oxide consumption: a prospective observational pilot study. Crit Care 2012;16(3): R95.

8. Dumont L, AuBuchon J. Evaluation of proposed FDA criteria for the evaluation of radiolabeled red cell recovery trials. Transfusion 2008;48(6): 1053-60.

9. Adias TC, Moore-Igwe B, Jeremiah ZA. Storage related haematological and biochemical changes of CDDA-1 whole blood in a resource limited setting. J Blood Disorders Transf 2012;3 DOI: 10.4172/2155-9864.1000124

10. Kim-Shapiro DB, Lee J, Gladwin MT. Storage lesion: role of red blood cell breakdown.Transfusion 2011;51(4):844-51.

11. Bennett-Guerrero E, Veldman TH, Doctor A, et al. Evolution of adverse changes in stored RBCs. PNAS. 2007;104(43): 7063-8.

12. Hardwick J. Blood storage and transportation. ISBT Sci Series 2014;3: 177-96.

13. Ratcliffe JM, Elliott MJ,Wyse RKH, Hunter S, Alberti KGMM. The metabolic load of stored blood. Implications for major transfusions in infants. Arch Dis Child 1986;61:1208-14

14. Hess JR. Measures of stored red blood cell quality.Vox Sang 2014;107(1): 1-9.

15. Hess JR. An update on solutions for red cell storage.Vox Sang 2006;91(1): 13-9.

16. Hess JR. Scientific problems in the regulation of red blood cell products. Transfusion 2012;52(8): 1827-35.

17. Delobel J, Garraud O, Barelli S, et al. Storage lesion: history and perspectives. World J Hematol 2015;4(4):54-68.

18. Makroo RN, RainaV,Bhatia $A$, et al.Evaluation of the red cell hemolysis in packed red cells during processing and storage. Asian JTransfus Sci $2011 ; 5$ (1): 15-7.

19. Flatt JF, Bawazir WM, Bruce LJ. The involvement of cation leaks in the storage lesion of red blood cells. Frontiers in Physiology 2014;5(365):214.

20. Mustafa I, Al Marwani A, Mamdouh Nasr K, Abdulla Kano N, Hadwan T. Time dependent assessment of morphological changes: leukodepleted packed red blood cells stored in SAGM. Biomed Res Int 2016;2016:4529434.

21. Wallas $\mathrm{CH}$. Sodium and potassium changes in blood bank stored human erythrocytes. Transfusion 1979;19(2):210-5.

22. Verma M, Dahiya K, Malik D, et al. Effect of blood storage on complete biochemistry. Blood Disord Transfus 2015,6: DOI: 10.4172/21559864.1000329.

23. Tayer AH, Amirizadeh N, Mghsodlu M, Nikogoftar M, Deyhim MR, Ahmadinejad M. Evaluation of blood storage lesions in leuko-depleted red blood cell units. Iran JPed Hematol Oncol 2017;7 (3): 171-9.

24. Reyes N, Gadsby DC. Ion permeation through the Na+-K+-ATPase. Nature 2006;443(7110):470-4

25. Opoku-Okrah C. Acquah BKS, Dogbe EE. Changes in potassium and sodium concentrations in stored blood. Pan African Med J 2015;20:236-42.

26. Tan KL, Tan IK. Plasma potassium, sodium, and chloride levels during and after exchange transfusion. Aust Paediatr J 1975; 11(3): 165-8.

27. Klein HG, Spahn DR, Carson JL. Red blood cell transfusion in clinical practice. Lancet 2007;370(9585):415-26.

28. Bansal I, Calhoun BW, Joseph C, Pothiawala M, Baron BW.A comparative study of reducing the extracellular potassium concentration in red blood cells by washing and by reduction of additive solution. Transfusion 2007;47(2):248-50.

29. Sheldon GF, Lim RC, Blaisdell FW. The use of fresh blood in the treatment of critically injured patients.J Trauma 1975;15(8):670-7.

30. Linko K, Saxelin I. Electrolyte and acid-base disturbances caused by blood transfusions. Acta Anaesthesiol Scand 1986;30(2):139-44.

31. Kim P, Chin-Yee I, Eckert K, et al. Hemolysis with rapid transfusion systems in the trauma setting. Can J Surg 2004;47(4):295-7.

32. Hall TL, Barnes A, Miller JR, Bethencourt DM, Nestor L. Neonatal mortality following transfusion of red cells with high plasma potassium levels. Transfusion 1993;33(7):606-9.

33. Vraets A, Lin Y, Callum JL. Transfusion-associated hyperkalemia. Transfus Med Rev 2011;25(3): 184-96.

34. Kozlova E, Chernysh A, Moroz V, Sergunova V, Gudkova O, Manchenko E. Morphology, membrane nanostructure and stiffness for quality assessment of packed red blood cells. Sci Rep 2017;7:7846.

35. Brito MVH, Cunha ICC, Aragon MG, Braga TGM, de Lima FD. Effects of blood storage on ice in biochemical band arterial blood gas analysis of rats. Acta Cir Bras 2008;23(5):462-8.

36. Raza S, Baig MA, Chang C, et al. A prospective study on red blood cell transfusion related hyperkalemia in critically ill patients. J Clin Med Res 2015;7(6):417-21.

37. Smith HM, Farrow SJ, Ackerman JD, Stubbs JR, Sprung J. Cardiac arrests associated with hyperkalemia during red blood cell transfusion: a case series. Anesth Analg 2008;106(4): 1062-9.

38. Sihler KC, Napolitano LM. Complications of massive transfusion. Chest 2010;137(1):209-20.

39. Knichwitz G, Zahl M, Van Aken H, Semjonow A, Booke M. Intraoperative washing of long-stored packed red blood cells by using an auto-transfusion device prevents hyperkalemia. Anesth Analg 2002;95(2):324-5.

40. Rowe JW, Tobin JD, Rosa RM, Andres R. Effect of experimental potassium deficiency on glucose and insulin metabolism. Metabolism 1980;29(6): 498502.

41. Clausen T,Everts ME. Regulation of the Na,K-pump in skeletal muscle. Kidney Int 1989;35(1): 1-13.

42. Uvizl R, Klementa B, Adamus M, Neiser J. Biochemical changes in the patient's plasma after red blood cell transfusion. Signa Vitae 2011;6(2):64-71.

43. Bailey DN, Bove JR. Chemical and hematological changes in stored CPD blood.Transfusion 1975;15(3):244-9

44. Latham JT Jr, Bove JR, Weirich FL. Chemical and hematologic changes in stored CPDA-1 blood.Transfusion 1982;22(2): 158-9.

45. Adrogue HJ, Madias NE. Changes in plasma potassium concentration during acute acid-base disturbances. Am J Med 1981;71(3):456-67.

46. Sezdi M, Bayik M, Ulgen Y. Storage effects on the Cole-Cole parameters of erythrocyte suspensions. Physiol Meas 2006;27 (7):623-35.

47. Lacroix J, Hebert P, Fergusson D, et al. The age of blood evaluation (ABLE) randomized controlled trial:study design. Transfus Med Rev2011;25(3):197-205.

48. Almac $\mathrm{E}$, Ince $\mathrm{C}$. The impact of storage on red cell function in blood transfusion. Best Pract Res Clin Anaesthesiol 2007:21 (2): 195-208.

49. Hamasaki N, Yamamoto M. Red blood cell function and blood storage. Vox Sang 2000;79(4): 191-7

50. Yoshida T, Shevkoplyas SS. Anaerobic storage of red blood cells. Blood Transfus 2010;8(4):220-36.

51. Gokce G, Citil M, Gunes V, Atalan G. Effect of time delay and storage temperature on blood gas and acid-base values of bovine venous blood. Res Vet Sci 2004;76(2): 121-7. 